\title{
The Impact of the FMA Guidelines of Non-GAAP Earnings Disclosures
}

\author{
Elizabeth A. Rainsbury ${ }^{\dagger}$ \\ Department of Accounting and Finance, Unitec New Zealand \\ Private Bag 92025, \\ Auckland 1140, New Zealand. \\ Email: erainsbury@unitec.ac.nz
}

Carol Hart

Department of Accounting and Finance, Unitec New Zealand Private Bag 92025,

Auckland 1140, New Zealand.

Email: chart@unitec.ac.nz

Corresponding Author: tDr Elizabeth Rainsbury, Department of Accounting and Finance, Unitec New Zealand, Private Bag 92025, Auckland, New Zealand. Telephone: +64 98154321 x 8803.

Email: erainsbury@unitec.ac.nz 


\subsection{Introduction}

This paper investigates whether disclosure guidelines issued by the New Zealand Financial Markets Authority changed the non-GAAP reporting policies of New Zealand companies. Financial markets authorities were concerned that company managers might use non-GAAP financial measures to mislead users. The New Zealand Financial Markets Authority responded in 2012 introducing guidelines that were to be applied from 2013. The guidelines (FMA 2012) were intended to reduce the potential non-GAAP information to be misleading by ensuring that they: (1) are not given undue prominence in investor communications, (2) are reconciled to the audited financial information, (3) are calculated consistently from period to period and is unbiased (FMA, 2012).

Prior research in the United States has examined the impact of regulation on the reporting of non-GAAP earnings. Studies have shown that the impact of SEC regulations implemented in 2003 improved disclosure practices and led to less mispricing of securities (Marques 2006, Entwistel, Feltham and Mbagwu 2006). In this paper we assess the consequences of guidelines in lieu of regulation. We examine whether there was a reduction in the frequency of the reporting of nonGAAP earnings and whether the quality of disclosures improved. It is the first study to provide evidence on the response by New Zealand listed companies New Zealand Financial Markets Authority guidelines. The study also adds to a very small body literature assessing the impact of guidelines rather than regulations on non-GAAP reporting. We find that there has been little change in the disclosure practices of New Zealand listed companies. We note with concern the frequent prominence given to non-GAAP earnings in preference to audited statutory profit.

The next section we compare some different approaches taken by capital market regulators to mitigate the risk that company managers might use non-GAAP earnings measures to mislead market participants. It also summarises empirical evidence on the impact of the use of regulations (in the United States) and the use of recommendations (in Europe) on non-GAAP disclosure practices. Section Three explains the research questions and Section Four provides a description of the sample 
sample and research design. The results are presented and discussed in Section Five while Section Six provides our conclusions derived from the results.

\section{Literature Review}

Background

There are two competing motives to explain managers' behaviour to disclosure of non-GAAP earnings. The first is that managers disclose non-GAAP as a means of communicating information about (or signalling) firm performance (Bhattacharya et al. 2003, Brown and Sivakumar 2003, Bowen, et al. 2005; Lougee and Marquardt 2004). An alternative explanation is that manager's report opportunistically, using non-GAAP earnings to convey a more favourable impression of reported earnings as a way of influencing users' perceptions of managerial performance (Bhattacharya et al., 2004, Bowen et al. 2005). An example is managers excluding expenses when doing so allows them to meet earnings benchmarks (Black and Christensen, 2009 and Doyle, Jennings and Soliman, 2013). However, non-GAAP measures are calculated in different ways by companies and are not audited.

Regulation

Regulators and professional accounting bodies have raised concerns about the use of alternative performance measures reported outside the audited financial statements in press releases and other documents (McLaughlin, 2010; FMA, 2011). Regulators acknowledge that while NGE may provide useful information to users there is also the potential to mislead them (FMA, 2011, 2012). In order to maintain market confidence various regulators have introduced regulations, recommendations or guidelines for issuers to follow when disclosing non-GAAP earnings.

In the United States the Sarbanes Oxley Act 2002 required the Securities and Exchange Commission (SEC) to address NGE disclosures. SEC Regulation G (SEC, 2003) was issued and made effective from March 2013. The regulation requires that where a firm publicly discloses information 
that includes a non-GAAP financial measure that it must provide (1) a directly comparable GAAP measure; and (2) reconcile the differences between the non-GAAP measure and the GAAP measure.

Where such information is filed with the SEC firms must also give reasons why management considers the non-GAAP information is useful to investors and additional purposes for which the financial measure is used.

In Europe governing non-GAAP earnings reporting best practice recommendations were issued by the Committee of European Securities Regulators1 (CESR) in 2005. The recommendations outline that pro forma earnings measures should be defined and the differences between the statutory and pro forma measure be explained.

Currently the European Securities and Markets Authority (ESMA) (2014) is revising the guidelines and undertaking a consultation process. The guidelines are intended to be mandatory. ESMA acknowledges that alternative performance measures (APMs) are often used by issuers to enable users to better understand the business, its underlying drivers and impact of external influences. ESMA identifies problems with disclosures including difficulties in reconciling the information. APM definitions are not always provided or applied consistently. They also suggest that APMs are used in a biased manner in reporting on performance.

The revised guidelines are aimed at making the APMs relevant, consistent and comparable. All APMs used are to be defined and applied consistently along with an explanation of their relevance for users. APMs have to be reconciled to the financial statements and comparative figures from precious periods provided. APMs are to be presented with less prominence that GAAP measures.

There are currently no regulations with respect to the disclosure of non-GAAP earnings in Australia and New Zealand, but both countries have guidelines. Australian listed companies are encouraged to follow guidelines issued by the Australian Institute of Company Directors and the Financial Services Institute of Australasia (2009). In addition, the Australian Securities and Investment Commission (ASIC) (2011) Regulatory Guide 230 requires that non-GAAP earnings

\footnotetext{
${ }^{1}$ Now reformed as the European Securities and Markets Authority
} 
should not be included in the statutory financial statements but only in the notes to those financial statements when it is necessary to give a true and fair view. Non-GAAP earnings are permitted in other communications such as directors' reports, press releases and analyst briefings but they must not be misleading or be given greater prominence than GAAP financial information. A reconciliation between non-GAAP earnings and GAAP earnings would also be required along with explanations of the adjustments. Consistent with the ESMA proposed guidelines the measures have to be prepared consistently from period to period and comparative figures provided.

In September 2012, New Zealand's FMA released a guidance note on disclosure of non-GAAP financial information for issuers, their directors and preparers of financial information. The guidelines set out expectations on the use of financial information in corporate documents and require a reconciliation between NGE and GAAP earnings along with explanations of the adjustments. The guidance note covers the definition of what the FMA considers as non-GAAP information. It also includes disclosure requirements to reduce the risk that the information may be misleading to users. Ten disclosure requirements are listed in the guidance note and are summarised in Table 1.

Table 1 Presentation of non-GAAP information

\begin{tabular}{|c|c|}
\hline Criteria & \\
\hline 1. Directors justification & $\begin{array}{l}\text { Directors must provide a statement of why the non-GAAP information } \\
\text { is useful to investors. }\end{array}$ \\
\hline 2. Lack of prominence & $\begin{array}{l}\text { Non-GAAP information must not be disclosed in such a way to give it } \\
\text { undue prominence, emphasis or authority }\end{array}$ \\
\hline 3. Labelled & $\begin{array}{l}\text { Non-GAAP information has to be labelled to clearly differentiate it } \\
\text { from GAAP information. }\end{array}$ \\
\hline $\begin{array}{l}\text { 4. Narrative explanation of } \\
\text { calculation }\end{array}$ & $\begin{array}{l}\text { How the non-GAAP financial information is calculated must be } \\
\text { explained }\end{array}$ \\
\hline $\begin{array}{l}\text { 5. Reconciliation with GAAP } \\
\text { financials }\end{array}$ & $\begin{array}{l}\text { A reconciliation of non-GAAP and GAAP information is to be disclosed. } \\
\text { Significant adjustments need to be disclosed separately and linked to } \\
\text { the financial statements or an explanation of how it is calculated. }\end{array}$ \\
\hline 6. Consistent approach & $\begin{array}{l}\text { A consistent approach to the calculation of non-GAAP information is } \\
\text { to be applied. Any changes in approach have to be explained along } \\
\text { with the financial impact of the change. }\end{array}$ \\
\hline 7. Non-GAAP adjustments & Comparative information to also be adjusted \\
\hline 8. Unbiased & Non-GAAP adjustments should not over(under)state good(bad) news. \\
\hline 9. Use of term "one-off" & $\begin{array}{l}\text { Non-GAAP adjustments are not be referred to as "one-off" if they } \\
\text { have occurred in the past and are likely to occur in the future. }\end{array}$ \\
\hline
\end{tabular}


10. Derived from audited or reviewed financial
A clear statement is to be made if non-GAAP financial information is obtained from audited or reviewed financial statements

Impact of Regulation $G$ in the United States

In the United States the introduction of disclosure regulations resulted in an initial reduction in the disclosure of non-GAAP earnings (Marques, 2006, Entwistle, Feltham and Mbagwu, 2006) Research studies also find that companies reduce the use of reporting non-GAAP earnings higher than GAAP earnings (Entwistle, Feltham, and Mbagwu, 2006)), less likely to reach analyst forecasts (Heflin and Hus, 2008) and less emphasis to discussing non-GAAP earnings in press releases (Entwistle, Feltham and Mbagwu, 2006).

The quality of items excluded from non-GAAP earnings is found to improve after regulation, with items excluded being more transitory than core items (Kolev, Marquardt and McVay, 2008). Investors reaction to non-GAAP earnings is higher in the post regulation period indicating that they have more confidence in the reporting, but they are more sensitive to aggressive (benchmarking beating) non-GAAP earnings reporting (Black, Black, Christensen and Heninger, 2012).

Overall the research indicates that the regulations improved disclosures in ways that are unlikely to mislead investors. However, there is still evidence of opportunistic behaviour (Baumaker, Biggs, McVay and Pierce, 2014).

\section{Impact of European Recommendations}

Hitz (2010) examines the impact of the European recommendations on proforma earnings disclosures in press releases from 2005-2006 for a sample of listed companies on the Frankfurt Stock Exchange, finding that the recommendations had little impact on disclosure practices and that the transparency of adjustments to earnings was low. In contrast, Aubert and Grudrutski (2014), using a sample of companies listed on the Euro STOXX Fixed Index, find that high quality reconciliations reduce the impact of mispricing of securities associated with pro forma disclosures. 
Cameron et al. (2012) focus on the reporting of non-GAAP earnings in the annual report prior to the ASIC guidelines. They compared the relative emphasis given to GAAP versus non-GAAP earnings among Australian firms over the three year period 2007-2009 prior to the implementation of the guidelines. They found that many companies emphasise proforma earnings in preference to statutory profit and in sixty per cent of cases proforma earnings was higher. They conclude that "impression management" is the most common motivation for managers to emphasise non-GAAP earnings. To date no research is available on the impact of the ASIC guidelines.

\section{Research Questions}

The FMA guidelines do not prohibit the disclosure of non-GAAP earnings but establish when they should or should not be disclosed and how non-GAAP earnings should be presented to ensure the information is not misleading (FMA, 2012). The introduction of the guidelines and monitoring by the FMA may discourage firms from making non-GAAP disclosures. The first research question is:

\section{Research Question 1}

Does the number of New Zealand listed companies disclosing non-GAAP earnings decline from 2012 to 2013 ?

The FMA guidelines are issued to avoid misleading investors. The potential to mislead may results from non-GAAP earnings being used to increase earnings, smooth earnings and to meet earnings benchmarks strategic earnings benchmarks (Black and Christensen, 2009, Barth et al., 2012). Given the FMA's intention to monitor disclosures it is expected that there will be a reduction in the number of firm using non-GAAP earnings to achieve strategic earnings benchmarks. The second research question is.

\section{Research Question 2}

Does the number of New Zealand listed companies disclosing non-GAAP earnings to meet strategic earnings benchmark decline from 2012 to 2013 ? 
The FMA guidelines cover disclosure of non-GAAP earnings in annual reports (excluding the financial statements), market announcements, and presentations to analysts or investors. The FMA provides guidance on ensuring the disclosures are not misleading as summarised in Table 1 . The third research question considers if the guidelines improve the quality of disclosures.

\section{Research Question 3}

Does application of FMA guidance on presentation of non-GAAP information in annual reports, improve from 2012 to 2013 ?

\section{Sample and Research Method}

The FMA guidelines (2012) were effective for non-GAAP financial information disclosures from $1^{\text {st }}$ January 2013. The population consists of all firms listed on New Zealand's stock exchange the NZX in 2013, the year of the introduction of the guidelines. The annual reports of each of the firms are examined to identify instances of non-GAAP reporting.

The sample is all firms that reported non-GAAP earnings in 2013 and 2012 so that the impact of the FMA guidelines on NGE disclosures can be examined. Only the year 2013 is selected to analyse any changes in disclosures as a longer time series may be impacted by a number of other factors (Heflin and Hsu, 2008).

Table 1 summarises the 2013 and 2012 samples.

\section{[Insert Table 1]}

The annual reports are examined for the sample of companies 2012 and 2013 . Non-GAAP reconciliation data is hand collected from the reports to record the difference between GAAP and non-GAAP earnings and the differences between them. The frequency of NGE reporting and the nature of non-GAAP adjustments are compared. In addition non-GAAP earnings are compared with strategic benchmarks. 
The quality of disclosures in annual reports is measured against the FMA guidelines using a quality index. Disclosure indices are a valid research tool (Botosan, 1997; Hooks and van Staden, 2011) and are used widely in accounting research. However, they are also considered difficult to apply because of issues about what defines disclosure quality and that assessing disclosure quality is often context specific (Botosan, 2004). These issues are mitigated in this research study in the following ways. First the disclosure quality is defined in terms of the disclosure benchmarks, guidance notes and illustrations for presentation of non-GAAP earnings produced by the FMA. Second, although the FMA guidelines are to apply to a range of communications to investors ${ }^{2}$, we limit the context to information provided in annual reports. Third we limited the analysis to definition of non-GAAP earnings to measures which incorporate adjustments made to the statutory earnings figure - net profit after tax prepared in accordance with GAAP. References to other nonGGAP earnings measures such as EBIT and EBITDA are ignored.

A scale is used to calculate the quality score. Appendix 1 illustrates how each of the criteria in Table 1 is scored and provides reference to the research literature to support the measure. In most cases the scoring is straightforward when a binary score of 1 or zero is used. For example, in Table 1, Criterion 6 consistency, is coded 1 if a consistent approach is applied to the calculation of non-GAAP information or zero if it is not. In other cases a more complex measure is used, such as the measurement of prominence as shown in Appendix 2. An assessment scale of 1 to 5 is used; a score of 1 is given for high prominence of non-GAAP earnings such as the appearance in a headline without reference to GAAP earnings. A score of 5 is given for where the main discussion is of GAAP earnings with non-GAAP earnings having secondary importance.

All scores are moderated by two researchers and differences agreed and then aggregated to achieve a score. A high score indicates higher quality of disclosure in terms of the FMA guidance.

\footnotetext{
2 The FMA (2012) guidelines apply to non-GAAP financial information included in company information released in investor communications, other than financial statements and transaction documents.
} 


\section{Results}

Table 1 shows the frequency of non-GAAP reporting. In 201324 out of 107 (22\%) companies reported non-GAAP earnings and 24\% (24 out of 102) in 2012. There are 24 companies reporting non-GAAP earnings in each year. Thus the Financial Market Authority Guidelines have not reduced the number of companies reporting non-GAAP earnings.

Of 24 companies reporting non-GAAP earnings in 2012, three did not report them in 2013. The 2013 companies reporting non-GAAP earnings include the 21 companies from 2012, and three additional companies including one newly listed company. Table 2 summarises the sample descriptive statistics. Companies reporting non-GAAP earnings are larger more profitable and have lower gearing compared with other listed companies. These differences are all statistically significant.

\section{[Insert Table 2]}

We examine if the reported non-GAAP earning are used to strategically beat benchmarks. Based on Marques (2010) four benchmarks are used: (1) non- GAAP earnings is greater than GAAP earnings (NGE $>$ NPAT $)_{t}$ (2) non-GAAP earnings reverses a GAAP loss i.e., NPAT $<0$ and NGE $>0$ (3) non-GAAP earnings is greater than the previous year's GAAP earnings but current GAAP earnings does not, i.e, NPAT $<$ NPATt-1 and NGE N $_{t}>\mathrm{NPAT}_{\mathrm{t}-1}$ and (d) non-GAAP earnings exceeds analysts' forecasts (AF) , but current GAAP earnings does not i.e., NPAT $T_{t}<A F N P A T_{t}<A F$. The results in Table 3 show little evidence of benchmark beating. In just over half of the companies, did non-GAAP earnings exceed audited net profit after tax (NPAT). There is only one case where non-GAAP earnings reverses a loss, four cases where non-GAAP earnings exceeds prior year earnings and NPAT does not, and seven cases where non-GAAP earnings exceed analysts' forecasts and NPAT does not.

\section{[Insert Table 3]}

Table 4 reports the disclosure scores for the 2012 and 2013 pro forma reporting companies. The scores range from a low of one to eight. The maximum score that can be achieved is 17 . The 
mean score is 5.71in 2012 and 6.17 in 2012 . The median score is six in both years. There has been a small improvement in disclosure quality but it is not significant ( $p$ value $=0.11$ )

Table 5 gives a break-down of the scores by category. What is clearly evident is there is little change in the disclosure scores by category.

As highlighted earlier in the paper our proforma earnings focus was on adjustments to the audited net profit after tax figure. All companies label non-GAAP earnings but use a range of names. Those used are: adjusted earnings, underlying earnings, normalised earnings, net distributable income, non-recurring income, abnormal earnings and net earnings before restructuring and impairment charges. The most common used is underlying earnings followed by and net distributable income which is used by property trust companies.

Twelve out of the 24 companies (50 per cent) justified the disclosure pro forma earnings compared with 10 out 24 (42 per cent) in 2012 . The most common justification is that proforma earnings are useful to investors and/or other users; five (two) times used in 2013 (2012). This was followed by non-GAAP earnings described as a better measure of operations and core business results (four (five) times used in 2013(2012) and assessing dividend distributions and debt covenant requirements (used four times in both 2013 and 2012).

In 201322 out of the 24 companies provided a reconciliation of net profit after tax with the pro forma earnings. The reconciliations are prepared consistently with comparatives provided with majority of the reconciliations moving from the GAAP to the non-GAAP earnings figures. However, the reconciliations are not accompanied by narrative explanations with only seven companies in 2013 that provided any form of narrative explanation; two of these were by footnote.

A concern is that in 2013 significant adjustments for 13 out of the 22 reconciliations were not linked to the financial statements. In a number of cases we could not trace the adjustments to the financial statements. 
The reconciliations do not give a clear statement that the non-GAAP financial information is obtained from audited or reviewed financial statements. This maybe because preparers consider that the source of information is obvious.

Of concern is the prominence given to non-GAAP earning by companies. In both years the prominence score is 3.0 indicating that non-GAAP earning disclosures take precedence over disclosures of GAAP earnings (see Appendix 1). This is contrast to the intention of the guidelines to ensure that "undue prominence, emphasis or authority is given to non-GAAP financial information" (FMA, 2012, p.9). The following are examples of prominence given to non-GAAP earnings. Example 1 shows normalised and net profit after tax given equal prominence in a financial brief presented on page 2 of the annual report.

Example 1

REPORTED PROFIT

AFTER TAX

\$3.0 million,

NORMALISED

TAX-PAID EARNINGS

$55 \%$ increase $\mathrm{fr}$

Example 2 is a summary of results presented on page 4 of the annual report. In this case underlying profit is emphasised but not net profit after tax.

\section{Example 2}

Strong performance

has provided solid returns

Total shareholder return

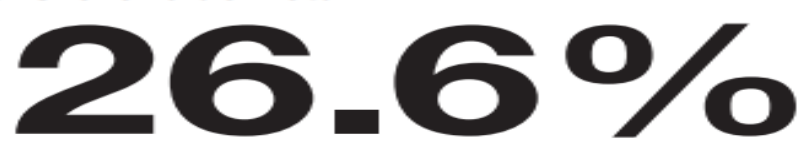

Dividends per share

(4)

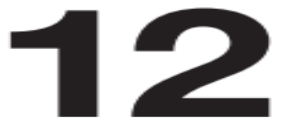

Up 14.3\%

Underlying profit

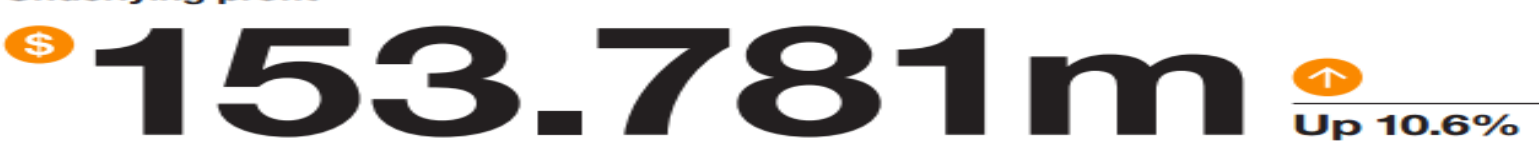


Example 3 shows the first sentence of the chairman's report highlighting underlying and not audited profit

\section{Example 3}

\section{CHAIRMAN'S REPORT}

\section{Underlying profit broke the}

$\$ 100$ m mark

I am delighted to report to you on

another successful year of growth

for the company.

\subsection{Conclusion}

This study examines the impact of guidelines issued by New Zealand's Financial Market Authority in 2012 on the disclosure of non-GAAP earnings by listed companies.

We examine the non-GAAP earning disclosures applying a disclosure index that rates the quality of disclosures in accordance with presentation criteria set out in the guidelines. We focus on adjustments to audited net profit after tax for 2012 and 2013, the year before and after the guidelines were introduced.

The results show just under a quarter of New Zealand listed companies disclose adjusted NPAT earnings. The guidelines had little impact on the number of firms disclosing non-GAAP earnings.

There is no standardisation in the labelling of non-GAAP earnings. Six different names were used for non-GAAP earnings - with the most frequently used being underlying earnings. All labels were used consistently in the annual report.

All but two of the companies provided reconciliations as required by the guidelines. However transparency is affected by the lack of explanations of the adjustments, referencing of the adjustments to the financial statements, and the source of the financial information.

Non-GAAP earnings are regularly disclosed prominently in comparison to GAAP earnings suggesting that presentation requirements are necessary but need to be complied with. 
In conclusion the implementation of the guidelines has had negligible impact on the frequency and quality of non-GAAP earnings disclosures. The results of this paper call for further investigation by the Financial Markets Authority of disclosure behaviour and ways to influence improvements. 
Table 1

Population in 2013 and 2012

\begin{tabular}{|c|c|c|c|c|}
\hline & 2013 & $\%$ & 2012 & $\%$ \\
\hline NZX All Index companies in 2013 & 110 & & 110 & \\
\hline $\begin{array}{l}\text { Less US company using GAAP, overseas company, no } \\
2013 \text { Annual Report }\end{array}$ & -3 & & & \\
\hline $\begin{array}{l}\text { Less US company using GAAP, overseas company, no } \\
2012 \text { Annual Report }\end{array}$ & & & -3 & \\
\hline Less companies listed in 2013 & & & -5 & \\
\hline Sub-total & 107 & 100 & 102 & 100 \\
\hline GAAP companies & 83 & 78 & 78 & 76 \\
\hline Non-GAAP earnings companies & 24 & 22 & 24 & 24 \\
\hline
\end{tabular}


Table 2

Descriptive Statistics

\begin{tabular}{|c|c|c|c|c|c|c|c|c|c|c|}
\hline & \multicolumn{2}{|c|}{ Mean } & \multicolumn{2}{|c|}{ Median } & \multicolumn{2}{|c|}{ Standard Deviation } & \multicolumn{2}{|c|}{ Maximum } & \multicolumn{2}{|c|}{ Minimum } \\
\hline & 2013 & 2012 & 2013 & 2012 & 2013 & 2012 & 2013 & 2012 & 2013 & 2012 \\
\hline All annual reports $(\mathrm{N})$ & 107 & 102 & 107 & 102 & 107 & 102 & 107 & 102 & 107 & 102 \\
\hline Market capitalisation (000) & 612,236 & 493,821 & 189,553 & 160,167 & $1,013,114$ & 852,947 & $5,758,525$ & $4,437,621$ & 220 & 660 \\
\hline Net profit after tax (000) & 34,195 & 28,846 & 11,528 & 7,927 & 71,079 & 57,522 & 337,000 & 311,000 & $-306,505$ & $-141,651$ \\
\hline Leverage & 0.50 & 0.51 & 0.42 & 0.43 & 0.52 & 0.68 & 4 & 7 & 0 & 0 \\
\hline $\begin{array}{l}\text { Non-GAAP earnings Companies } \\
\text { (N) }\end{array}$ & 24 & 24 & 24 & 4 & 24 & 24 & 24 & 24 & 24 & 24 \\
\hline Market capitalisation (000) & $1,412,480$ & $1,230,175$ & $1,072,977$ & 867,573 & $1,300,106$ & $1,316,765$ & 4,088450 & $4,437,621$ & 62,702 & 65,315 \\
\hline Net profit after tax $(000)$ & 85,029 & 73,952 & 71,906 & 42,800 & 68,527 & 79,306 & 238,000 & 311,000 & 1,894 & $-1,633$ \\
\hline Leverage & 0.48 & 0.49 & 0.47 & 0.50 & 0.16 & 0.19 & 1 & 1 & 0 & 0 \\
\hline Other Listed Companies (N) & 83 & 78 & 83 & 78 & 83 & 78 & 83 & 78 & 83 & 78 \\
\hline Market capitalisation (000) & 380,841 & 267,251 & 113,991 & 82,462 & 781,715 & 464,075 & $5,758,525$ & $2,680,000$ & 220 & 660 \\
\hline Net profit after tax $(000)$ & 19,496 & 15,314 & 5,400 & 5,640 & 65,105 & 40,980 & 337,000 & 198,767 & $-306,505$ & $-141,651$ \\
\hline Leverage & 0.51 & 0.52 & 0.41 & 0.40 & 0.58 & 0.77 & 4 & 7 & 0 & 1 \\
\hline \multicolumn{11}{|l|}{ t-stat } \\
\hline Market capitalisation & $\begin{array}{c}0.00 \\
(0.00)^{*}\end{array}$ & $\begin{array}{c}0.00 \\
(0.00)^{*}\end{array}$ & & & & & & & & \\
\hline Net profit after tax & $\begin{array}{c}0.03 \\
(0.00)^{*}\end{array}$ & $\begin{array}{c}0.00 \\
(0.00)^{*}\end{array}$ & & & & & & & & \\
\hline Leverage & $\begin{array}{c}0.05 \\
(0.13)^{*}\end{array}$ & $\begin{array}{c}0.18 \\
(0.12)^{*}\end{array}$ & & & & & & & & \\
\hline
\end{tabular}

Notes: Leverage is measured as the ratio of total liabilities to total assets ${ }^{*}$ Non-parametric 
Table 3

Comparing Non-GAAP Earnings to Strategic Benchmarks ( $\mathrm{N}=48)$

\begin{tabular}{|c|c|c|c|c|c|c|c|c|}
\hline \multirow[t]{2}{*}{ Year } & \multicolumn{2}{|c|}{$\begin{array}{l}\text { NGE Reporting } \\
\text { NGE Higher than } \\
\text { NPAT }\end{array}$} & \multicolumn{2}{|c|}{ NGE Negates a Loss } & \multicolumn{2}{|c|}{$\begin{array}{l}\text { NGE Negates an } \\
\text { Earnings Decrease }\end{array}$} & \multicolumn{2}{|c|}{$\begin{array}{l}\text { NGE Negates a Missed } \\
\text { Analyst Forecast }\end{array}$} \\
\hline & $\begin{array}{c}\text { NGE } \\
\text { Reports }\end{array}$ & $\begin{array}{l}\mathrm{NGE}_{t}> \\
\mathrm{NPAT}_{t}\end{array}$ & $\mathrm{NPAT}_{t}<0^{A}$ & $N G E_{t}>0^{B}$ & $\begin{array}{l}\text { NPAT }_{t}< \\
\text { NPAT }_{t-1} \mathrm{C}\end{array}$ & $\begin{array}{c}\mathrm{NGE}_{\mathrm{t}}> \\
\mathrm{NPAT}_{\mathrm{t}-1} \mathrm{D}\end{array}$ & $\begin{array}{c}\mathrm{NPAT}_{\mathrm{t}} \\
\mathrm{E}\end{array}$ & $\underset{F}{\mathrm{NGE}_{\mathrm{t}}}>\mathrm{AF}_{\mathrm{t}}$ \\
\hline 2013 & 24 & 12 & 0 & 0 & 7 & 2 & 7 & 1 \\
\hline 2012 & 24 & 13 & 1 & 1 & 6 & 2 & 10 & 6 \\
\hline Total & 48 & 25 & 1 & 1 & 13 & 4 & 17 & 7 \\
\hline$\%$ & & $52 \%$ & & $100 \%$ & & $31 \%$ & & $41 \%$ \\
\hline
\end{tabular}

Notes: $\mathrm{NGE}_{t}$ is the non-GAAP earnings in current year, NPAT $\mathrm{t}_{t}$ is the NZ GAAP earnings in current year, NPAT ${ }_{1}$, is the NZ GAAP earnings in the prior year, AF is the average analyst forecast for the current year's profit. 
Table 4

Disclosure Scores

\begin{tabular}{|c|c|c|c|}
\hline Companies & 2013 & 2012 & Difference \\
\hline 1 & 6 & 7 & -1 \\
\hline 2 & 7 & 7 & 0 \\
\hline 3 & 7 & 6 & 1 \\
\hline 4 & Not NGE & 4 & N/A \\
\hline 5 & 6 & 6 & 0 \\
\hline 6 & 5 & 6 & -1 \\
\hline 7 & 8 & 7 & 1 \\
\hline 8 & 6 & 5 & 1 \\
\hline 9 & 6 & 6 & 0 \\
\hline 10 & Not NGE & 4 & N/A \\
\hline 11 & 4 & 4 & 0 \\
\hline 12 & 6 & 6 & 0 \\
\hline 13 & 3 & Not NGE & N/A \\
\hline 14 & 6 & 6 & 0 \\
\hline 15 & 6 & 5 & 1 \\
\hline 16 & 7 & $\begin{array}{r}\text { Listed in } \\
2013 \\
\end{array}$ & N/A \\
\hline 17 & 5 & 5 & 0 \\
\hline 18 & 7 & Not NGE & N/A \\
\hline 19 & 8 & 8 & 0 \\
\hline 20 & 5 & 5 & 0 \\
\hline 21 & 7 & 1 & 6 \\
\hline 22 & Not NGE & 6 & N/A \\
\hline 23 & 7 & 7 & 0 \\
\hline 24 & 8 & 8 & 0 \\
\hline 25 & 6 & 7 & -1 \\
\hline 26 & 5 & 5 & 0 \\
\hline 27 & 7 & 6 & 1 \\
\hline $\mathrm{N}$ & 24 & 24 & t-stat \\
\hline Mean Score & 6.17 & 5.71 & p-value 0.11 \\
\hline Std Dev & 1.24 & 1.52 & \\
\hline Median Score & 6.00 & 6.00 & \\
\hline Sum & 148 & 137 & \\
\hline Max & 8 & 8 & \\
\hline Min & 3 & 1 & \\
\hline
\end{tabular}

Note: Maximum score potential is 17 
Table 5

Summary of Disclosure Index Scores by Category

\begin{tabular}{|l|c|c|c|c|}
\hline Criteria & \multicolumn{2}{|c|}{ Yes } & \multicolumn{2}{c|}{ No } \\
\hline & 2013 & 2012 & 2013 & 2012 \\
\hline Directors justification & 12 & 10 & 12 & 14 \\
\hline Labelled & 24 & 24 & 0 & 0 \\
\hline Narrative explanation of calculations & 7 & 5 & 17 & 19 \\
\hline Reconciliation with GAAP financials & 22 & 20 & 2 & 4 \\
\hline Consistent approach & 23 & 23 & 1 & 1 \\
\hline Comparatives of non-GAAP adjustment & 22 & 20 & 2 & 4 \\
\hline Unbiased & 14 & 14 & 10 & 10 \\
\hline Not using the term “one-off” & 19 & 17 & 5 & 7 \\
\hline Derived from audited or reviewed financial & 5 & 4 & 19 & 20 \\
\hline statements & & & & \\
\hline & Average & & \\
\hline Lack of prominence* & 2013 & 2012 & & \\
\hline t-stat p-value & 3.04 & 3.00 & & \\
\hline$*$ Possible scores are from 1 to 5 & & 0.41 & & \\
\hline
\end{tabular}

*Possible scores are from 1 to 5 


\section{Appendix 1 Disclosure Index}

\begin{tabular}{|c|c|c|c|}
\hline & & Coding & Reference \\
\hline Directors Justification & $\begin{array}{l}\text { Directors must provide a statement of why the } \\
\text { non-GAAP information is useful to investors. }\end{array}$ & $\begin{array}{l}\text { Disclosure Score } \\
1=\text { Yes; } 0=\text { No } \\
\text { Sub-coding } \\
\text { Code statements. The statements can cover more than one of the } \\
\text { categories below: } \\
\text { 1. better measure of operations or more indicative of core } \\
\text { business results } \\
\text { 2. } 2 \text { useful to investors and/or other users } \\
\text { 3. used by management for internal purposes } \\
\text { 4. improves consistency and/or comparability } \\
\text { 5. used for assign dividend distribution and debt covenant } \\
\text { 6. No justification } \\
\text { 7. Other }\end{array}$ & Webber et al. (2013) \\
\hline Lack of Prominence & $\begin{array}{l}\text { Non-GAAP information must not be disclosed in } \\
\text { such a way to give it undue prominence, } \\
\text { emphasis or authority }\end{array}$ & $\begin{array}{l}\text { Disclosure score } 1 \text { to } 5 \\
\text { 1. Appearance in headline: Non-GAAP earnings in a headline of the } \\
\text { directors' report and management commentary (press release) } \\
\text { but NOT GAAP earnings. } \\
\text { 2. Appearance in graphical presentation: Non-GAAP earnings is } \\
\text { reported in a graphic in directors report and management } \\
\text { commentary (press release) but NOT GAAP earnings. } \\
\text { 3. Pro Forma dominates: Discussion of non-GAAP earnings clearly } \\
\text { takes precedence over GAAP earnings. These include: } \\
\text { 3.1 where non-GAAP earnings is mentioned in the first page } \\
\text { of the directors or management commentary (first } \\
\text { paragraph of the press release) but NOT GAAP earnings, } \\
\text { or } \\
\text { where commentary on performance given throughout } \\
\text { the directors report and management commentary } \\
\text { (press release) relates primarily to non-GAAP earnings } \\
\text { with few comments on GAAP earnings, or } \\
\text { 3.3 GAAP earnings is presented but not commented in } \\
\text { directors or management commentary (press release), } \\
\text { or } \\
\text { GAAP profit figure and reconciliation ARE NOT contained } \\
\text { in the directors or management commentary(press }\end{array}$ & $\begin{array}{l}\text { Entwistle et al. (2006) } \\
\text { and FMA(2012) }\end{array}$ \\
\hline
\end{tabular}




\begin{tabular}{|c|c|c|c|}
\hline & & $\begin{array}{l}\text { release) } \\
4 \text { GAAP and non-GAAP earnings are equally prominent: Discussion } \\
\text { of both measures is mentioned at the same rate. For example, } \\
\text { whenever a pro forma measure is mentioned, the equivalent } \\
\text { GAAP measure is also mentioned. } \\
5 \text { GAAP dominates: Discussion of GAAP earnings clearly take } \\
\text { precedence over non-GAAP earnings. These include } \\
5.1 \quad \begin{array}{l}\text { where GAAP earnings is mentioned in first page in the } \\
\text { directors or management commentary (first paragraph } \\
\text { of the press release) but NOT non-GAAP earnings, or }\end{array} \\
5.2 \text { where commentary on performance given throughout } \\
\text { the directors report and management } \\
\text { commentary(press release) relates primarily to GAAP } \\
\text { earnings with few comments on non-GAAP earnings, or } \\
5.3 \text { Non-GAAP earnings is presented but not commented in } \\
\text { directors or management commentary. (press release), } \\
\text { or } \\
\text { GAAP profit figure and reconciliation ARE contained in } \\
\text { the directors or management commentary(press } \\
\text { release) }\end{array}$ & \\
\hline Labelled & $\begin{array}{l}\text { Non-GAAP information has to be labelled to } \\
\text { clearly differentiate it from GAAP information. }\end{array}$ & $\begin{array}{l}\text { Disclosure Score } \\
\text { 1=Yes -non-GAAP labelled consistently; otherwise } 0 \\
\text { Sub-coding } \\
\text { Classify the terminology given to the non-GAAP earnings figure } \\
\text { 1. Non-GAAP earnings } \\
\text { 2. Core earnings } \\
\text { 3. Adjusted earnings } \\
\text { 4. Underlying earnings } \\
\text { 5. Earnings after adjustments } \\
\text { 6. Normalised } \\
\text { 7. Other Label } \\
\text { Label used consistently Yes/No }\end{array}$ & \\
\hline $\begin{array}{l}\text { Narrative Explanation } \\
\text { of Calculation }\end{array}$ & $\begin{array}{l}\text { How the non-GAAP financial information is } \\
\text { calculated must be explained }\end{array}$ & $\begin{array}{l}\text { Disclosure Score } \\
1=\text { Yes if calculation is explained; otherwise } 0 \text { explained } \\
\text { Sub-coding } \\
\text { Classify how the explanation was given: } \\
\text { 1. Explanation within narrative of directors or management } \\
\text { commentary(press release) } \\
\text { 2. Explanation within narrative plus support from director internal } \\
\quad \text { policy Explanation in footnote }\end{array}$ & \\
\hline
\end{tabular}




\begin{tabular}{|c|c|c|c|}
\hline & & 3. Explanation by footnote & \\
\hline \multirow[t]{2}{*}{$\begin{array}{l}\text { Reconciliation with } \\
\text { GAAP financials }\end{array}$} & $\begin{array}{l}\text { A reconciliation of non-GAAP and GAAP } \\
\text { information is to be disclosed. }\end{array}$ & $\begin{array}{l}\text { Disclosure Score } \\
1=Y e s \text { if reconciliation is given explained; } 0=\text { if no reconciliation } \\
\text { Sub-coding } \\
\text { 1. Side by side } \\
\text { 2. Move from GAAP to non-GAAP showing the adjustments } \\
\text { 3. Move from non-GAAP to GAAP showing the adjustments } \\
\text { 4. Other }\end{array}$ & Marques (2010) \\
\hline & $\begin{array}{l}\text { Significant adjustments need to be disclosed } \\
\text { separately and linked to the financial } \\
\text { statements or an explanation of how it is } \\
\text { calculated. }\end{array}$ & $\begin{array}{l}\text { Disclosure Score } \\
1=Y e s \text { if adjustments can be identified in the financial statements or } \\
\text { calculation shown; otherwise } 0\end{array}$ & \\
\hline Consistent Approach & $\begin{array}{l}\text { A consistent approach to the calculation of non- } \\
\text { GAAP information is to be applied. }\end{array}$ & $\begin{array}{l}\text { Disclosure Score } \\
1=\text { Same adjustments as prior year, otherwise, } 0\end{array}$ & \\
\hline $\begin{array}{l}\text { Non-GAAP } \\
\text { Adjustments }\end{array}$ & Comparative information to also be adjusted & $\begin{array}{l}\text { Disclosure Score } \\
1=Y e s, 0=\text { No }\end{array}$ & \\
\hline Unbiased & $\begin{array}{l}\text { Non-GAAP adjustments should not } \\
\text { over(under)state good(bad) news. }\end{array}$ & $\begin{array}{l}\text { Disclosure Score } \\
1=\text { Neutral: non-gaap earning presented in an unbiased way in } \\
\text { reference to company performance. } \\
0=\text { Good news: non-gaap earnings presented in a positive way in } \\
\text { reference to the company's performance } \\
0=\text { Bad news: non-gaap earning presented in a negative in reference } \\
\text { to the company's performance }\end{array}$ & \\
\hline Use of term "one-off" & $\begin{array}{l}\text { Non-GAAP adjustments are not to be referred } \\
\text { to as "one-off" if they have occurred in the past } \\
\text { and are likely to occur in the future. }\end{array}$ & $\begin{array}{l}\text { Disclosure Score } \\
1=\text { Recurring items are not referred to as "one-off" items , } 0 \\
\text { otherwise }\end{array}$ & \\
\hline $\begin{array}{l}\text { Derived from audited } \\
\text { or reviewed financial }\end{array}$ & $\begin{array}{l}\text { A clear statement is to be made if non-GAAP } \\
\text { financial information is obtained from audited } \\
\text { or reviewed financial statements }\end{array}$ & $\begin{array}{l}\text { Disclosure Score } \\
1=\text { a clear statement as to audited or reviewed financial information, } \\
\text { otherwise, } 0\end{array}$ & \\
\hline
\end{tabular}




\section{References}

Australian Securities and Investment Commission (2011), Disclosing non-IFRS information. available at: http://www.asic.gov.au/asic/pdflib.nsf/LookupByFileName/rg230-published-9december-2011.pdf/\$file/rg230-published-9-december-2011.pdf (accessed 13 March 2014).

Barth, M., Gow, I. \& Taylor, D. (2012). Why do pro forma and street earnings not reflect changes in gaap? Evidence from SFAS 123R. Review of Accounting Studies, 17, 526-562.

Baumaker, M. Biggs, P., McVay, S. E., \& Pierce, J. (2014). The disclosure of non-gaap earnings following regulation G: An analysis of transitory gains. Accounting Horizon, 28 (1), 77-92.

Bhattacharya, N., Black, E., Christensen, T. \& Larson, C. (2003). Assessing the relative informativeness and permanence of pro forma earnings and gaap operating earnings. Journal of Accounting and Economics, 36, 285-319.

Black, D. E. \& Christensen, T. (2009). US managers' use of 'pro forma' adjustments to meet strategic earning targets. Journal of Business Finance and Accounting, 36 (3), 297-326.

Black, D. E., Black, E. L., Christensen, T. \& Heninger, W. G. (2012). Has the regulation of pro forma reporting in the US changed investors' perceptions of pro forma earnings disclosures? Journal of Business Finance and Accounting, 39 (7), 876-904.

Brown, L. and Sivakumar, K. (2003). Comparing the relevance of two operating income measures. Review of Accounting Studies, 8, 561-572.

Botosan, C. A. (1997). Disclosure level and the cost of equity capital. The Accounting Review, 72(3), 323-349.

Botosan, C. A. (2004). Discussion of a framework for the analysis of firm risk communication. The International Journal of Accounting, 39, 289-295.

Bowen, R., Davis, A. and Matsumoto, D. (2005). Emphasis on pro forma versus gaap earnings in quarterly press releases: Determinants, SEC intervention, and market reactions. The Accounting Review, 80(4), 1011-1038.

Clatwothy, M. \& Jones, M. J. (2003). Financial reporting of good news and bad 
news: evidence from accounting narratives. Accounting and Business Research, 33 (3), 171-185.

Entwistle, G. M.Feltham< G. D. and Mbagwu, C. (2006). Financial reporting and the reporting of pro forma earnings. Accounting Horizons, 20 (1), 39-55.

European Securities and Markets Authority. (2014). ESMA guidelines on alternative measures. Retrieved from http://www.esma.europa.eu/content/ESMA-Guidelines-Alternative-Performance$\underline{\text { Measures }}$

Financial Markets Authority. (2012). Guidance note: Disclosing non-gaap financial information. Retrieved from http://www.fma.govt.nz/media/1027578/guidance_note_-_disclosing_nongaap_financial_information.pdf.

Heflin,F and Hsu, C. (2008). The impact of SEC's regulation on non-gaap disclosures. Journal of Accounting and Economics, 46, 349-365.

Hooks, J. \& van Staden. C. J. (2011). Evaluating environmental disclosures: The relationship between quality and extent measures. The British Accounting Review, 43, 200-213.

Kolev, Marquardt and McVay, (2008). SEC scrutiny and the evolution of non-gaap reporting. The Accounting Review, 83 (1), 157-184.

Lougee, B. \& Marquardt, C. (2004). Earnings informativeness and strategic disclosure: An empirical examination of "non-GAAP" earnings". The Accounting Review, 79(3), 769-795.

Marques, A. (2010). Disclosure strategies among S\&P 500 firms: Evidence on the disclosure of non-GAAP financial measures and financial statements in earnings press releases. British Accounting Review, 42, 19-131.

Rainsbury, E., Hart, C. and Buranavityawut, N. (2013). Non-GAAP earnings disclosures in New Zealand. Pacific Accounting Review, forthcoming.

Securities and Exchange Commission. (2003) Regulation G: Final Rule: Conditions for use of non-gaap financial measures. Retrieved form http://www.sec.gov/rules/final/33-8176.htm 
Street, D., Webber, S., Nichols, N., Cereola, S. (2013). Non-GAAP adjustments to net income appearing in the earnings releases of the S\&P 100: An analysis of frequency of occurrence, materiality and rationale. Research in Accounting Regulation, 25 (2), 236-51. 